International Journal of Instruction

e-ISSN: 1308-1470 • www.e-iji.net

Article submission code:

20200512171252

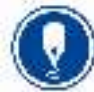

Received: 12/05/2020

Revision: 28/12/2020
July $2021 \bullet$ Vol.14, No.3

p-ISSN: 1694-609X

pp. 481-500

Accepted: 23/01/2021

OnlineFirst: 22/05/2021

\title{
Metacognitive on Pteridophyte: A Unification of Cooperative Integrated Reading and Composition and Guided Inquiry (CirGI)
}

\section{Mieke Miarsyah}

Biology Education, Faculty of Mathematic and Sciences, Universitas Negeri Jakarta, Indonesia,mmiarsyah@unj.ac.id

\section{Rizhal Hendi Ristanto}

Biology Education, Faculty of Mathematic and Sciences, Universitas Negeri Jakarta, Indonesia, rizhalhendi@unj.ac.id

\section{Puji Lestari}

Biology Education, Faculty of Mathematic and Sciences, Universitas Negeri Jakarta, Indonesia, pujilestari25472@gmail.com

\section{Sri Rahayu}

Biology, Faculty of Mathematic and Sciences, Universitas Negeri Jakarta, Indonesia, srirahayu@unj.ac.id

Pteridophyte classification has undergone many changes both from morphology as well as phylogeny aspects. Thus, a variety of learning experiences are required to promote understanding on concepts and managing learning activities-this study aimed at determining the impact of CIRGI and CirGi Unification on students' metacognitive skills. A quasi-experiment was applied with pre-post control group design. The sample used was 70 students of Botany Phanerogam class at Universitas Negeri Jakarta, Indonesia. Data was collected with metacognitive skills, student questionnaire responses to learning, and observation sheet of syntax implementation. The metacognitive test instrument was verified as valid and reliable. One-way ANCOVA was used as data analysis technique. This study's conclusion revealed that there was an influence of CIRC and CirGi unification on the student's metacognitive skills. The influence was higher compared to those using conventional learning models.

Keywords: metacognitive skills, CIRC and CirGi unification, pteridophyte, skills, learning

\section{INTRODUCTION}

Cryptogamic botany is the study of low-level plants, one of which is Pteridophyte (Lestari et al., 2019a; Meishanti et al., 2018; Tjitrosoepomo, 2006; Guo et al., 2003).

Citation: Miarsyah, M., Ristanto, R. H., Lestari, P., \& Rahayu, S. (2021). Metacognitive on pteridophyte: A unification of cooperative integrated reading and composition and guided inquiry (CirGI). International Journal of Instruction, 14(3), 481-500. https://doi.org/10.29333/iji.2021.14328a 
Some of the learning objectives lead to activities to develop learning experiences (Inayah et al., 2020; BSNP, 2006), critical thinking skills, analytical, inductive, and deductive (Bustami et al., 2020; Hamdani et al., 2020; Hayati \& Berlianti, 2020; Corebima, 2016), and interrelated principles on identifying and classifying activity (Tjitrosoedirdjo \& Chikmawati, 2014; Smith et al., 2006). The achievement of learning objectives is closely related to someone's independence in learning and how to manage their learning. This independence is related to a person's metacognitive planning, organizing, managing, and knowing how to monitor his thinking or cognitive processes (Ismirawati et al., 2020; Sari et al., 2020; Hindun et al., 2020; Dedić, 2014; Howard, 2004; Ramdiah \& Corebima, 2014). Metacognitive skills play an important role in successful learning, leading to higher-order thinking skills, including active control of cognitive processes in learning and everyday life (Lestari et al., 2019b; Sarah et al., 2016; Mariati, 2012; Livingston, 2003).

Metacognitive skills have a role in determining one's learning success because it train someone to be an independent learner that leads to the ability to understand and control the learning environment (Handayani \& Widiantie, 2020; Yasir et al., 2020; Schraw et al., 2006). Metacognitive skills also play an important role in cognitive activities, such as understanding, communication, attention, retention, memory, and problem-solving (Ismirawati et al., 2020; Howard, 2004). Metacognitive skills and understanding of concepts are part of the ability to think at a higher level, following Biological characteristics that have the potential to empower thinking skills (Lestari et al., 2019b; Basith, 2012).

The importance of metacognitive skills in achieving learning goals is not in line with existed facts. The complexity of the material, such as identification and taxonomy, is quite high between each species (Suraida, 2012), the number of subdivisions of distribution making it difficult to distinguish the characteristics of each division (Hanif \& Rohman, 2016), so there are foreign terms and concepts the abstract, as to develop the ability to think, required to be able to understand the main concepts through reasoning, find related concepts, or make connections between concepts with various ways of learning (Miharja et al., 2019; Hayati, 2016). Another fact of weak metacognitive skills is learning models in learning activities (Pratama, 20118; Palennari, 2016; Mariati, 2012). In practice, learning has used student-centered learning models, but the tendency to wait for lecturers' orders causes students to be less independent and uninformative in finding subject matter (Djamhar et la., 2019; Kusumaningtias et al., 2013). Thus impacting on weak awareness in students' metacognitive skills (Halimah, 2014), inefficient using appropriate learning strategies, so learning is only memorized, which causes a weak understanding of student concepts (Ardila et al., 2012). The use of learning models used so far still revolves around discussions, presentations, and is emphasized more in lectures that are not by syntax and doesn't come from a variety of supporting sources (Hanif \& Rohman, 2016; Corebima, 2016). Students should be allowed to explore understanding, develop concepts, develop thinking skills (Mariati, 2012). Based on these data, an effort is needed to strengthen students' metacognitive skills to achieve learning objectives. According to Mariati (2012); Fauziah (2013); Walker (2012), that one way to strengthen understanding of concepts is to apply 
learning models and manage their metacognition to be able to construct knowledge, deepen and apply the concepts of learning to give rise to scientific answers that represent understanding.

One of the required learning models is unifying the CIRC learning model and guided inquiry (Ristanto et al., 2018). This learning model is a diffusion of two models, namely Cooperative Integrated Reading and Composition (CIRC) and guided inquiry. The virtue of integrating several models is the complementary strengths and weaknesses of several learning models (Fitriyani et al., 2015; Prayitno, 2012).

The strengths of CIRC include practicing integrated skills between reading and finding the main ideas of discourse or material and giving responses in writing (Christina \& Kristin, 2016), encouraging individuals to hone their ability to learn independently, to remind the activities of each group effectively in various aspects (Harahap et al., 2020; Sukiastini, 2013). However, the CIRC places more emphasis on reading, writing, and communication activities, and only involves a small number of scientific processes that form the basis of learning Biology (Ristanto et al., 2020; Djamhar et al., 2020; Christina \& Kristin, 2016). At the same time, guided inquiry consists of stages exposing students to problems analysis and evaluation with the potential to improve metacognitive skills (Pratiwi et al., 2019; Bahiyah et al., 2019; Fitriyani et al., 2015). This will increase their metacognitive skills because students solve their problems by conducting investigations and analyzing data (Pratama, 2018; Prayitno, 2012). However, it is more suitable to be applied to students who have high academic and consistency in syntax implementation because they must complete the material in a long time with an investigation (Darmwan et al., 2018; Jannah, 2015).

Based on the two learning models mentioned, another strategy needs to be done related to each model's strengths and weaknesses by integrating them. According to Ristanto (2017), this unification of the CIRC learning model and guided inquiry is strived to improve student-centered understanding of concepts that emphasize reading and writing activities on applying learning steps based on the lecturer's scientific methods direction. The study that unified CIRC and Guided Inquiry has been designed well on the biology learning kit (Ristanto et al., 2018). It has revealed its effectivity in enhancing critical thinking skills in the ecosystem (Harahap et al., 2020). Information on the impact of CirGi on the metacognitive of Botani Pheneroghame subject hasn't been found yet so far. Based on these facts, research needs to be done related to students' metacognitive skills to achieve learning objectives. A learning model that aligns with these two aspects is integrating CIRC and guided inquiry (CirGI). The research aims to determine the effect of students' metacognitive skills through the unification of CIRC and guided inquiry in the Cryptogamic Botany of Pteridophyte at Universitas Negeri Jakarta, Indonesia. 


\section{METHOD}

\section{Research Design}

A quasi-experiment was used in this research, the design where two groups were chosen randomly. Pretest and posttest were then assessed at the end of learning to investigate differences between an experiment and a control group (Sugiyono, 2015).

Table 1

Research design pretest and posttest control group design

\begin{tabular}{llll}
\hline Class & Pretest & Treatment & Postest \\
\hline $\mathrm{E}(\mathrm{R})$ & $\mathrm{T}_{1}$ & $\mathrm{X}$ & $\mathrm{T}_{3}$ \\
\hline $\mathrm{C}(\mathrm{R})$ & $\mathrm{T}_{2}$ & 0 & $\mathrm{~T}_{4}$ \\
\hline
\end{tabular}

E: experiment class (integration of CIRC And guided inquiry), C: Control class (CIRC learning model application), R: Sample was chosen randomly, X: treatment, 0: control, $\mathrm{T}_{1,2}$ : Pretest, $\mathrm{T}_{3,4}$ : Postest

\section{Participant}

This study's population was students of Biology Education, Faculty of Mathematics and Natural Sciences Universitas Negeri Jakarta Academic year 2018/2019 taken botany cryptogam. Step for sampling includes purposive sampling to decide Universitas Negeri Jakarta as a targetted population or respondents. Identify all students from the targeted population and decide affordable population with simple random sampling (McClave). The prerequisite test of normality and homogeneity was followed by an equality test to decide sample equity using students' pretest and posttest.

\section{Instrument}

The instrument used in this study is metacognitive refer to the indicators of Schraw et al. (2006) includes planning, monitoring, and evaluating. Metacognitive rubric scoring was done based on Corebima (2009). The metacognitive instrument grid can be seen in Table 2.

Table 2

Students' metacognitive instrumen grid

\begin{tabular}{ll}
\hline Indicator & Test Number \\
\hline $\begin{array}{l}\text { Planing } \\
\text { Planning, setting goals, and allocating things prioritized to be studied }\end{array}$ & $2,4,7,10$ \\
\hline $\begin{array}{l}\text { Monitoring } \\
\text { Assess learning or use of strategies }\end{array}$ & $1,5,8,11$ \\
\hline $\begin{array}{l}\text { Evaluating } \\
\text { Analyze what has been done and effective strategies after education have been conducted }\end{array}$ & $3,6,9,12$ \\
\hline
\end{tabular}

\section{Procedure}

This study consisted of three stages; the first stage starts with (1) Observation of students of Biology Education, Universitas Negeri Jakarta; (2) Preparation of experiment needs such as students' worksheet and metacognitive skills instrument. The second stage was the implementation part; every student was assigned for a pretest on 
metacognitive skills in an essay. Each group was given the same treatment on the basic competence and subject material but not on the treatment. CirGi treated the experiment group during control with conventional one.

The CirGi learning model's implementation combines CIRC learning and Guided Inquiry (Harhap et al., 2020; Ristanto, 2017). CirGi has five learning stages, which are first, the formation of heterogeneous groups. In this stage, students are grouped into 3 to 4 students with different academic abilities and genders. The second stage is reading, discussing, and discovering the main concepts of reading. At this stage, students analyze the two main sources of calcification of mosses and their characteristics from Smith et al. (2006) and Tjitrosoepomo (2015) as well as two sources of research results on plants from accredited national journals and reputable international journals. The analysis results are written on a student worksheet in the format of the title or topic of the material being studied, reading sources, important facts about the material being analyzed, questions that arise from the results of group discussions. The results of the questions that arise are than being discussed on the extent of the hypothesis.

Further, they are consulted with the lecturer on the relevance of the topic to be published. This activity is the initial stage of Pterydophyta learning activities through guided inquiry. Students work together in groups and, with the guidance of lecturers, carry out advanced learning activities in the form of experiments and literature reviews to answer questions that have been formulated. The results of reading analysis and research are then written as a learning report. At the end of the worksheet arrangement, students are asked to conclude and write down their learning reflections. The results of reading analysis and scientific investigations were presented and continued with class discussions. CirGi learning design is shown in Figure 1. Subject material was conducted based on the learning design planned on each group.

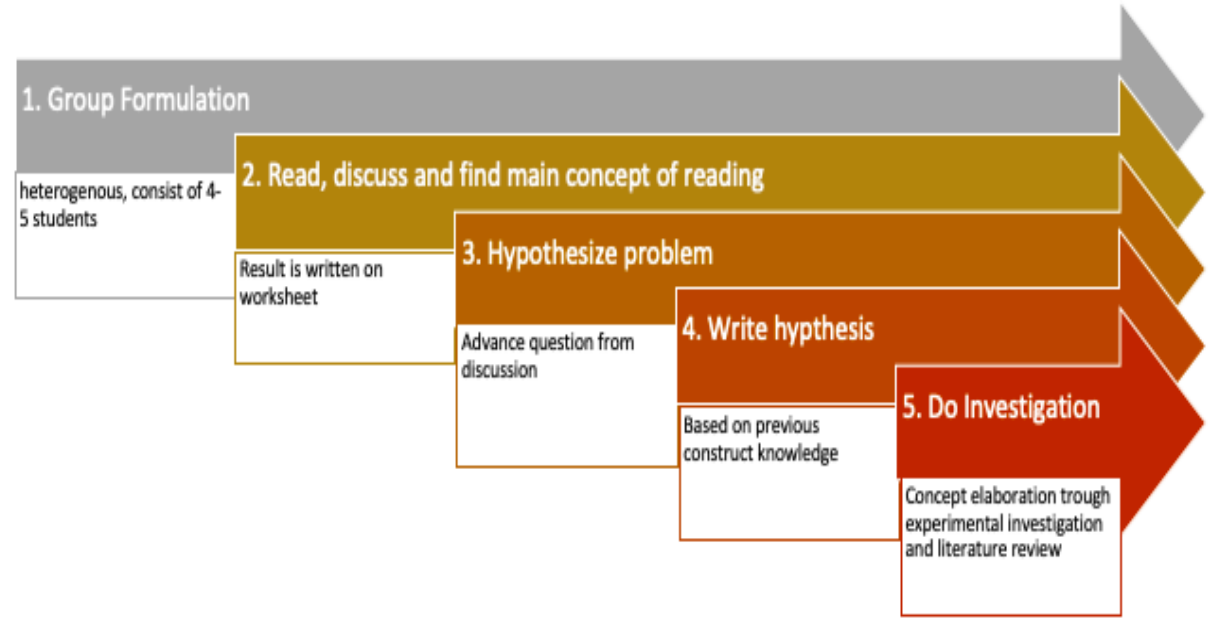

Figure 1

CirGi learning syntax 
The third stage is the final treatment phase by assigning post- test to measure students' metacognitive skills achievement. Data was then processed for drawing conclusions and test the hypothesis that has been stated before. Learning was done three meeting times on the evert group.

\section{Data Analysis}

Data analysis of this research was descriptive, prerequisite analysis, correlation, and hypothesis test. Descriptive tests include averages and standard deviations. Normality test was done with Kolmogorov-Smirnov, while homogeneity test was analyzed with Levene. Correlation test aimed at determining whether the variables allegedly was confounding variable (Convarian) related to the dependent variable or the variable to be measured. Hypothesis testing was done using the covariance analysis technique (Anacova) with a significance level of $\alpha=0.05$. All tests were done with significance level of $\alpha=0.05$ with SPSS 24 Software.

\section{FINDINGS}

\section{Normality}

Based on Table 3, the experimental class showed the pretest p-value of 0.095 and the posttest of 0.681 greater than $\alpha=0.05$, so it can be concluded that the pretest and posttest data of the metacognitive skills of students in the experimental class were normally distributed. In the control class, the pretest's p-value was 0.791 . The posttest $\mathrm{p}$ value was 0.305 greater than $\alpha=0.05$, so it can be concluded that the pretest and posttest data of students' metacognitive skills in the control class were also normally distributed.

Table 3

Pretest and posttest normality on students' metacognitive skill

\begin{tabular}{|c|c|c|c|c|}
\hline \multirow{2}{*}{ Class } & \multirow{2}{*}{$\Sigma$ sample } & \multicolumn{2}{|c|}{ Metacognitive skill } & \multirow{2}{*}{ Note } \\
\hline & & Pretest & Pos-test & \\
\hline Experiment & 35 & 0.127 & 0.574 & Normal \\
\hline Control & 35 & 0.791 & 0.305 & Normal \\
\hline
\end{tabular}

\section{Homogeneity}

Homogeneity was conducted Based on the analysis of the data that has been done. The homogeneity testing of students' metacognitive skills data was carried out with Levine's test with $\alpha=0.05$. The calculation results show that $\alpha=0.162>0.05$ or $\mathrm{H}_{0}$ was accepted so that it can be interpreted that the average pretest and posttest of students' metacognitive skills in the group of students who applied the CIRC integration learning model and guided inquiry and the group of students who applied conventional learning models have the same variance or homogeneous. 


\section{Correlation}

The correlation was carried, based on the analysis of the data that has been done, data correlation testing was performed with the Pearson product-moment with $\alpha=0.05$. The results of the analysis can be seen in Table 4.

Table 4

Pretest and posttest correlation on students' metacognitive skill

\begin{tabular}{llll}
\hline Component & Sub-component & Pretest & Posttest \\
\hline \multirow{3}{*}{ Pretest } & Pearson Correlation & 1 & $0.359^{* *}$ \\
\cline { 2 - 4 } & Sig. (2-tailed) & 70 & 0.002 \\
\cline { 2 - 4 } Post-test & $\mathrm{N}$ & $0.359^{* *}$ & 70 \\
\hline & Pearson Correlation & 0.002 & 1 \\
\cline { 2 - 4 } & Sig. (2-tailed) & 70 & 70 \\
\cline { 2 - 4 } & $\mathrm{N}$ & 70 & \\
\hline
\end{tabular}

Based on Table 4, the pretest score as a covariate has a significant correlation with the posttest score after treatment being given. This can be seen from the Pearson productmoment calculation, which is $r=0.359$, which was greater than $\alpha=0.05$, so it can be concluded that there is relationship between pretest and posttest and pretest is a variable that must be controlled (covariate).

Based on the results of the calculation of the pretest and posttest understanding of the Pteridophyte concept in the experimental class applied with the guided inquiry CIRC learning model, there was an increase with a difference of 24.37 where previously the pretest score had an average of 37.72, and the posttest had a mean of 62.07 (Table 5). This increase can be seen in all indicators of understanding the concept of Pteridophyte.

Table 5

Mean of pretest and posttest of metacognitive skill for each indicator on experiment class

\begin{tabular}{|c|c|c|c|c|c|}
\hline \multirow{2}{*}{ No } & \multirow{2}{*}{ Indicator } & \multicolumn{2}{|c|}{ CirGI } & \multicolumn{2}{|c|}{ Conventional } \\
\hline & & Pretest & Posttest & Pretest & Posttest \\
\hline 1 & $\begin{array}{l}\text { Planing } \\
\text { (planning, managing goal, allocate priority } \\
\text { item to be learned) }\end{array}$ & 40,61 & 62,55 & 36,33 & 53,27 \\
\hline 2 & $\begin{array}{l}\text { Monitoring } \\
\text { (Evaluating learning or strategy use) }\end{array}$ & 38,37 & 60,71 & 39,28 & 60,51 \\
\hline 3 & $\begin{array}{l}\text { Evaluation } \\
\text { (Analysis of what has been done and effective } \\
\text { strategy after learning conducted) }\end{array}$ & 34,18 & 62,96 & 31,53 & 57,14 \\
\hline Total & & 113,16 & 186,22 & 107,14 & 170,92 \\
\hline Mean & & 37,39 & 61,77 & 35,48 & 58,54 \\
\hline Devis & on standard & 8,92 & 11,68 & 6,75 & 8,29 \\
\hline
\end{tabular}


Based on Table 5 and Figure 2, it is known that there are increased on all indicators, the highest score found in the evaluation indicators, which were originally found in the average 34.18 to 62.96 with a difference of 28.78 and the percentage increase of $45.71 \%$. In contrast, the lowest score was the original planning indicator at an average of 40.61 to 62.55 , with a difference of 21.94 and a percentage increase of 35.08. Based on these data, it is known that students who are applied with the CIRC integration learning model and guided inquiry have been able to evaluate, such as analyzing what has been and effective strategies after the learning is carried out. Still, it is necessary to make a habit of planning, such as setting goals and allocating prioritized things.

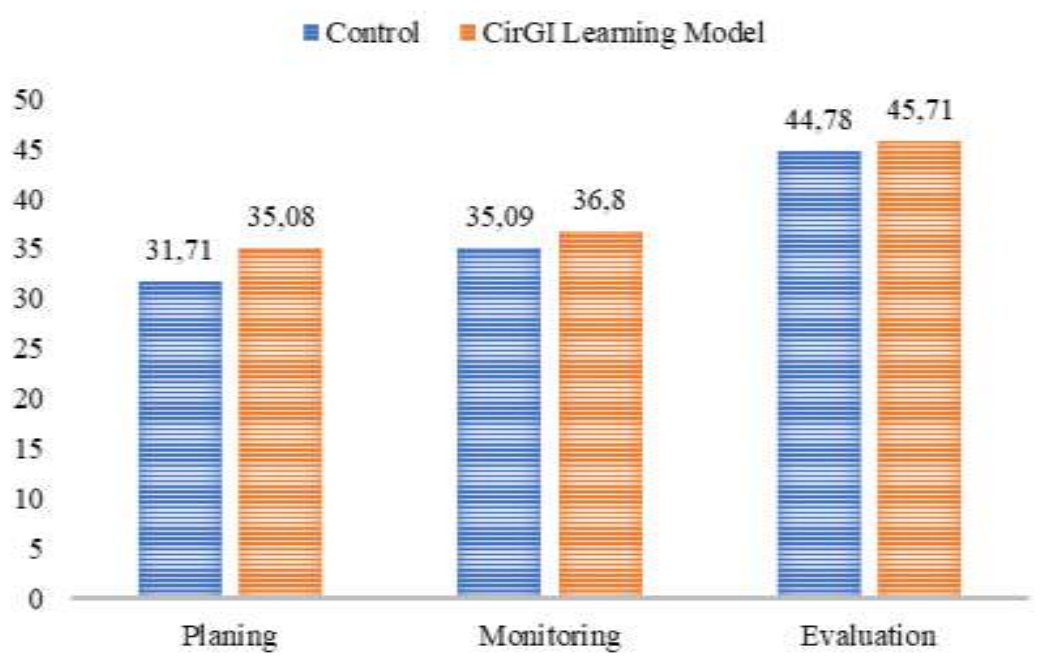

Figure 2

Increasement score percentage of metacognitive skills on experiment and control class

\section{Data Description of Student Metacognitive Skills}

Based on Figure 2, it is known that all indicators have increased the highest score found in the evaluation indicators, which were originally on the average of 39.28 to 60.51 with a difference of 21.23. The percentage increase of 44.78, while the lowest score was on the original planning indicator's average score at an average of 36.33 to 53.27. The difference is 16.94 , and the percentage increase is $31.71 \%$. Based on these data, it can be concluded that students who are applied with conventional learning models are able to evaluate, such as analyzing what has been done and the right learning strategies. Still, it is necessary to habituate in planning, setting goals, and allocating things prioritized for learning. Based on Table 4 and Figure 2, it is known that the pretest and posttest scores of students' metacognitive skills in the experimental class applied with the CirGI learning model were higher than the control class applied with the conventional learning model with a score difference of 3.09. The pretest score of the experimental class metacognitive skills was 37.72 , and the posttest of the students' metacognitive skills was around 62.07, with the difference between the two was 24.35 . Whereas in the control 
class applied with the conventional learning model, the pretest score of students' metacognitive skills was 35.71, and the posttest was 56.97, with a difference of 21.26. The mean of planning, monitoring, and evaluation indicators are more stable in the classrooms implemented with the CirGI learning model. The increase was in the average of 60.71-62.96 and above and stable in the mean score range, while in the control class applied with conventional learning models ranging from 53.27-60.51. In both classes, evaluation indicators get the highest score, and planning gets the lowest score. However, the two indicators still have the highest percentage increase in the experimental class applied by the guided CIRC-incur learning model compared to the control class (Figure 2). Mean differences per indicator and overall percentage increase from the metacognitive skills score. A t-test based on indicators was performed to determine the significance of the mean difference based on indicators. Based on Table 6, it can be seen that the significance of the t-test is smaller than 0.05 . So, it can be concluded that there are mean differences in each indicator of the metacognitive skills of students in the class applied to the learning model of integrated learning CIRC and guided inquiry with classes applied by conventional learning models.

Table 6

Independent sample t-test on students' metacognitive skill indicators of experiment and control class

\begin{tabular}{llll}
\hline No. & Indicator & $\begin{array}{l}\text { t-test significance } \\
\text { between variable }\end{array}$ & Conclusion \\
\hline 1 & $\begin{array}{l}\text { Planing } \\
\text { (planning, managing goal, allocating priority } \\
\text { thing to be learned) }\end{array}$ & 0.008 & $\begin{array}{l}\text { mean } \\
\text { difference }\end{array}$ \\
\hline 2 & $\begin{array}{l}\text { Monitoring } \\
\text { (Evaluating learning or strategy use) }\end{array}$ & 0.049 & $\begin{array}{l}\text { mean } \\
\text { difference }\end{array}$ \\
\hline 3 & $\begin{array}{l}\text { Evaluation } \\
\text { (Analysis of what has been done and effective } \\
\text { strategy after learning) }\end{array}$ & 0.039 & $\begin{array}{l}\text { mean } \\
\text { difference }\end{array}$ \\
\hline
\end{tabular}

Note: $[\alpha>0.05=$ no mean difference $] ;[\alpha<0.05=$ mean difference $]$

Based on data analysis, hypothesis testing was done with ANCOVA with $\alpha=0.05$. The analysis result can be seen in Table 7 . 
Table 7

ANCOVA test of students' metacognitive skill

\begin{tabular}{llllll}
\hline Source & Type III Sum of Squares & Df & Mean Square & F & Sig. \\
\hline Corrected Model & $1275.781^{\mathrm{a}}$ & 2 & 637.891 & 8.825 & .000 \\
\hline Intercept & 4686.192 & 1 & 4686.192 & 64.834 & .000 \\
\hline Pretest & 634.935 & 1 & 634.935 & 8.784 & .004 \\
\hline Learning Model & 488.374 & 1 & 488.374 & 6.757 & .011 \\
\hline Error & 4842.738 & 67 & 72.280 & & \\
\hline Total & 258142.520 & 70 & & & \\
\hline Corrected Total & 6118.519 & 69 & & & \\
\hline
\end{tabular}

Based on the results of calculations that have been done, it can be seen that the pretest value has a $\mathrm{p}$-value $=0.004<\alpha=0.05$, so $\mathrm{H}_{0}$ was rejected (Table 7). This means that there are differences in students' average metacognitive skills between students taught with the CirGI learning model and the conventional learning model after controlling for the posttest's influence. The results of the calculation of the learning model variables show that the $\mathrm{p}$-value $=0.011<\alpha=0.05$ so that $\mathrm{H}_{0}$ is rejected. This means that without the pretest value in the confidence level of $95 \%$, there is an influence of applying learning models in groups applied with the CirGI learning model and conventional learning models on the posttest score of concept understanding obtained by students.

Table 8

Post hoc test on students' metacognitive skill

\begin{tabular}{|c|c|c|c|c|c|c|}
\hline \multirow{2}{*}{ Parameter } & \multirow{2}{*}{$\mathrm{B}$} & \multirow{2}{*}{ Std. Error } & \multirow{2}{*}{$\mathrm{T}$} & \multirow{2}{*}{ Sig. } & \multicolumn{2}{|c|}{ 0.05 Confidence Interval } \\
\hline & & & & & Lower Bound & Upper Bound \\
\hline Intercept & 41.404 & 5.447 & 7.601 & .000 & 30.532 & 52.277 \\
\hline Pretest & .436 & .147 & 2.964 & .004 & .142 & .730 \\
\hline $\begin{array}{l}\text { [CIRC and Guided } \\
\text { inquiry] }\end{array}$ & 5.321 & 2.047 & 2.599 & .011 & 1.235 & 9.408 \\
\hline [konvensional] & $0^{\mathrm{a}}$ & & & & & \\
\hline
\end{tabular}

Based on the analysis results in Table 8 , it can be seen that CirGI has a p-value $=0.011$ $0.0 \alpha=0.05$. So that $\mathrm{H}_{0}$ was rejected. It can be concluded that the posttest score of the metacognitive skills of students applied with CirGI is higher than students who applied conventional learning after being controlled by a pretest.

\section{DISCUSSION}

This study aimed to determine the effect of the CirGI learning model on students' metacognitive skills. Hypothesis testing showed that $\mathrm{H}_{0}$ is rejected because it was smaller than the significance level with $\alpha=0.05$. It can be concluded that there is an influence of the CirGI learning model on students' metacognitive skills. Further explanations will be discussed in each group. The results of descriptive data analysis 
and hypothesis testing indicate a significant influence of the CIRC integration learning model and guided inquiry on students' metacognitive skills (Table 6). These influences indicate that the metacognitive skills of students who applied the CIRC integration learning model and guided inquiry were higher than those of students who applied conventional learning models. Based on Table 4, it is known that students who are applied with the CirGI learning model have been able to evaluate the analyzing of what has been done (including reviewing the understanding of the definition of Pteridophyte, body structure, types of spores based on shape and size, metagenesis and classification Pteridophyte). Also, effective strategies after learning are carried out. Still, it is necessary to make a habit of planning, such as setting goals, strategies, and allocating things prioritized for learning. Table 7 shows that the effect of CirGI incur higher than conventional and can be seen from the syntax or stages.

In the first stage, students are forming a heterogeneous group. According to Ristanto \& Darmawan (2020) and Saputra et al. (2019), creating heterogeneous student groups aims to narrow students' academic abilities. Students with high academic skills will assist those with lower achievement (Yusuf et al., 2019; Mahanal et al., 2019). Students' metacognitive skills are also honed along with the time efficiency in learning. Because in completing assignments, students are required to adjust or use as much time as possible both in the division of components of the task itself or with other students, and set strategies appropriate learning to understand the material from various sources (AlGaseem et al., 2020; Hogan et al., 2015).

The second stage is reading, discussing, and conducting investigations. At the reading stage, it is carried out from various sources of reading in accordance with the Pteridophyte material component, which discusses the definition, structure of the body, metagenesis, and its benefits in daily life. According to Evangeline (2016) and Garcia et al. (2015), reading activities from various sources require students to analyze what material should be known in advance or prioritized, monitor their understanding of the many sources of reading, and evaluate the understanding and learning strategies used. Stages of discussion include activities that include an inquiry process based on the discussion component of the MFI, so that the stages run smoothly, the MFI needs to assist the investigation, which contains the discussion component and with direction from the lecturer. During the discussion, a lot of information is needed so that during the discussion between the material being learned or other material related to the material being discussed. Discussion with cooperative principles will help students under lower academic skills. Assistance is gained from other friends within the same group with a higher academic level. (Ristanto, Rahayu, \& Mutmainah, 2020; Leasa et al., 2019; Kritpracha et al., 2018). In this activity, planning, monitoring, and evaluation aspects are also related to learning materials or strategies, both within groups and students themselves, so that all information components in student worksheet are fulfilled so that they will hone students' metacognitive skills. This agrees with Rokhmat \& Putrie (2019) and Walker et al. (2012) that the opinions or arguments given during discussions have an important role in scientific reasoning, the development of conceptual understanding, and skills in constructing between material learned with other material. 
In the discussion component contained in the MFI also includes the third stage of formulating the problem, the fourth stage formulating hypotheses, and the fifth stage conducting investigations from various sources, and the sixth stage developing work based on planning, monitoring, and evaluation activities because between students encouraged to complete the discussion material before being presented. Each student in a heterogeneous group has a different assignment at the estimated time that has been done. These activities can hone students' metacognitive skills because when formulating problems and determining hypotheses. Students must understand in advance the material in which reading various sources support aspects of planning metacognitive skills (Ristanto et al., 2017; Prayitno et al., 2017; Prayitno, 2015). when they will develop material or conduct an investigation, students are able to formulate problems and determine hypotheses or provisional estimates of what will be investigated so that students' understanding is more directed and systematic that requires monitoring and evaluation aspects of the skills metacognitive (Widyasari et al., 2013).

The seventh stage is to analyze, evaluate the investigation process, and draw conclusions. Students are given a replication related to what has been obtained from the process of discussion in groups during the evaluation activities. When displaying the work, and what is not yet understood from the material that has been discussed, as well as evaluation of learning strategy errors that must be adjusted to the number of materials so that students' metacognitive skills in this aspect increases. Reflection is included in self-evaluation, which includes controlling the student's learning process, determining the stages of planning, selecting learning strategies that are appropriate to the components of the material being studied, monitoring progress, and correcting errors in understanding the concepts and effectiveness of the chosen learning strategies (Ristanto et al., 2020; Iskandar, 2014). Reflection activities in this learning are related to students' self-regulation of Pteridophyta. Students write down what they have learned, the constraints, and what strategies are used to overcome these obstacles. This reflection writing stage is relevant to the metacognitive dimensions, namely, planning, monitoring, and evaluating.

In contrast to the experimental class applied by the CirGI, in the control class applied to the conventional learning model, students' metacognitive skills are lower, which can be seen from the low aspects of planning (Figure 2). Although it has increased, the planning aspect has a lower percentage increase than other elements and the experimental class. This is likely due to the drafting of an MFI there was no component of problem formulation and hypothesis determination. Learning activities focus on discussion activities in groups and between groups. Still, development of important facts and fundamental concepts that lead to understanding from various sources has not been seen. This can be seen when presenting the work that has not been effective, and students who ask questions must be determined first. Activities formulate problems and hypotheses, including activities that will determine learning goals. The activity leads to student skills in planning, which includes setting goals, and allocating things that are prioritized to be studied, making it easier for students to understand the whole complex Pteridophyte material (Akben, 2020; Garcia et al., 2015; Cil, 2015). 
In addition to these two factors, another factor contributing to learning is the lecturer's guidance as a facilitator. Students who applied the conventional model had led to student-centered lecturers giving directions for completing assignments at the beginning of the meeting. Students actively discovered the main concepts from the reading sources. However, discussion activities between lecturers and students did not run well due to the absence of problem formulation and formulation of hypotheses, which became the direction for the development of the material discussed so that students only sought a basic definition or general understanding of the material, and were not enthusiastic when discussing with the lecturer. This because they were not raised knowledge about the differences in the discussion components that have been determined so that the lecturer only aligns or evaluates at the end of the course without accustoming self-reflection to students. High-quality students' worksheet is needed to implement learning design (Yusnaeni et al., 2019; Fajarianingtyas et al., 2019). CirGi implementation on biology learning needs clear worksheet so that students' will be able to conduct the assignment well (Harahap et al., 2019). According to Ristanto et al. (2018); Muna et al. (2016), activities that should have occurred during the preparation of the student's worksheet in addition to discussions with friends of a group, namely students can ask questions and discuss with the lecturer if there is a compilation component that is not yet understood so as to facilitate students at the time of the investigation, utilizing the lecturer as a source knowledge. Added by Dwi et al. (2013) and Lukitasari et al. (2014), this activity also honed students' skills in streamlining time for component investigations, which later had an impact on the customization of planning aspects that included things that had to be prioritized or not yet understood so that they could be discussed with the lecturer as a facilitator. According to Prayitno (2015), students' metacognitive skills habituation activities should be managed or designed in a planned and deliberate, systematic, and sustainable manner with facilitators such as lecturers during learning activities.

\section{CONCLUSION}

Based on the research that has been done, it is concluded that there is an influence of the CirGI learning model on students' metacognitive skills. The implications obtained from this study include that students can be directed or familiarized with reading and writingbased activities that can be accompanied by scientific activities. The integration of CIRC and guided inquiry (CirGI) can be used as an alternative choice of learning models to enhance or strengthen students' metacognitive skills. CirGi learning syntax combines two learning models of CIRC and Guided Inquiry so that the learning phase is longer. Students need a good understanding before studying Biology with CirGi. Recommendation based on this study limitation focuses on how teachers or lecturers provide more operational instruction on the worksheet.

\section{ACKNOWLEDGEMENT}

Gratitude is an address to all parties who have helped this research. Special thanks to Dr. Rusdi and Dr. Diana Vivanti Sigit for their ideas and recommendations during the research process. Thanks also address Dr. Ericka Darmawan and Dr. Nur Ismirawati to evaluate the metacognitive instrument on Botany Phanerogame lecture. 


\section{REFERENCES}

Al-Gaseem, M. M., Bakkar, B. S., \& Suhail, A. Z. (2020). Metacognitive thinking skills among talented science education students. Journal for the Education of Gifted Young Scientists, 8(2), 897-904.

Akben, N. (2020). Effects of the problem-posing approach on students' problem solving skills and metacognitive awareness in science education. Research in Science Education, 50(3), 1143-1165.

Ardila, C., Corebima, A.D., \& Zubaidah, S. (2013). Hubungan keterampilan metakognitif terhadap hasil belajar biologi dan retensi siswa kelas X dengan penerapan strategi Pemberdayaan Berpikir Melalui Pertanyaan (PBMP) Di SMAN 9 Malang. (Skripsi, Universitas Negeri Malang, 2013). Retrieved from http://jurnalonline.um.ac.id/data/artikel/artikelEE88BC4B01504CB71615F1D280FAF7 AE.pdf

Badan Standar Nasional Pendidikan. (2006). Standar Kompetensi Dan Kompetensi Dasar Sekolah Menengah Atas. Jakarta: Departemen Pendidikan Nasional.

Bahiyah, L., Sudarmin, S., \& Hartono, H. (2019). Analysis of Students Metacognitive Skill in Solving Problem on Guided Inquiry Learning Model. Journal of Innovative Science Education, 8(3), 248-254.

Basith, A. (2012). Potensi strategi Reciprocal Teaching untuk memberdayakan keterampilan metakognitif siswa sekolah menengah berkemampuan akademik rendah pada pembelajaran Biologi. Prosiding Seminar Biologi, 9(1), 84-89. Retrieved from: http://www.jurnal.fkip.uns.ac.id/index.php /prosbio/article/view/1028.

Bustami, Y., Leliavia, L., Elisabeth, N., Gandasari, A., \& Ratnasari, D. (2020). Contextual teaching learnıng in human digestive system: The contribution of critical thinking skills. Biosfer: Jurnal Pendidikan Biologi, 13(1), $101-113$. https://doi.org/10.21009/biosferjpb.v13n1.101-113

Christina, L. V., \& Kristin, F. (2016). Efektivitas model pembelajaran tipe group investigation (gi) dan cooperative integrated reading and composition (circ) dalam meningkatkan kreativitas berpikir kritis dan hasil belajar ips siswa kelas 4. Scholaria, 6(3), 217-230. https://doi.org/10.24246/j.scholaria.2016.v6.i3.p217-230

Cil, E. (2015). Integrating botany with chemistry \& art to improve elementary school children's awareness of plants. The American Biology Teacher, 77(5), 348-355. Retrieved from http://www.ucpressjournals.com/php?j=abt.

Corebima, A.D. (2016). Pembelajaran biologi di Indonesia bukan untuk hidup. Seminar Nasional XIII Pendidikan Biologi FKIP UNS, 13(1), 8-22. Retieved from https://jurnal.uns.ac.id/prosbi/article/view/5640.

Corebima, A.D. (2006). Metacognitive skill measurement integrated in achievement test. SM310509ADC. Retrieved from ftp.revsam.edu.my. 
Darmawan, E., Brasilita, Y., Zubaidah, S., \& Saptasari, M. (2018). Enhancing metacognitive skills of students with different gender using simas eric learning model at state senior high school 6 Malang. Biosfer: Jurnal Pendidikan Biologi, 11(1), 48-57. https://doi.org/10.21009/biosferjpb.11-1.5

D Ristić Dedić, Z. (2014). Metacognitive knowledge in relation to inquiry skills and knowledge acquisition within a computer-supported inquiry learning environment. Psihologijske teme, 23(1), 115-141. Retrieved from https://hrcak.srce.hr/120497

Djamahar, R., Ristanto, R. H., Sartono, N., \& Darmawan, E. (2020). Approaches to Respiratory and Excretion Systems Teaching: An Innovative Learning through Cirsa. Universal Journal of Educational Research, 8(6), 2204-2210. https://doi.org/10.13189/ujer.2020.080602

Djamahar, R., Ristanto, R. H., Sartono, N., Ichsan, I. Z., Darmawan, E., \& Muhlisin, A. (2019, June). Empowering student's metacognitive skill through Cirsa learning. Journal of Physics: Conference Series, 1227(1), 012001.

Dwi, I. M., Arif, H., \& Sentot, K. (2013). Pengaruh strategi Problem Based Learning berbasis ICT terhadap pemahaman konsep dan kemampuan pemecahan masalah Fisika. Jurnal Pendidikan Fisika Indonesia, 9(1), 8-17. Retrieved from https://journal.unnes.ac.id/nju/index.php/JPFI/article/view/2575

Evangeline, C. J. (2012). Examining the effect of metacognitive skill of performance of students. An International Peer Reviewed \& Referred SRJIS, 3(18), 4054-4059.

Fajarianingtyas, D. A., Akbar, N. A., \& Herowati, H. (2019). Developing students' worksheet based on scientific approach in cell as the system of life. Biosfer: Jurnal Pendidikan Biologi, 12(1), 109-121. https://doi.org/10.21009/biosferjpb.v12n1.109-121

Fauziah, D.Y., Corebima, A.D., \& Zubaidah, S. (2013). Hubunngan keterampilan metakognitif terhadap hasil belajar bioogi dan retensi siswa kelas $\mathrm{x}$ dengan penerapan strategi pembelajaran thing pair share di sma negeri 6 malang. Jurnal Online Universitas Negeri Malang. Retrieved from http://karya-ilmiah.um.ac.id

Fitriyani, R., \& Corebima, A. D. (2015). Pengaruh strategi pembelajaran Problem Based Learning dan inkuiri terbimbing terhadap keterampilan metakognitif, berfikir kritis, dan hasil belajar siswa. Jurnal Pendidikan Sains, 3(4), 186-200. https://doi.org/http://journal.um.ac.id/index.php /jps/ Jurnal

Garcia, T., Cueli., Rodriguez, C., Krawec, J., \& Castro, P.G. (2015). Metacognitive knowledge and skill in students with deep approach to learning evidence from mathematical problem solving. Revista De Psicodidactica, 20(2), 209-226.

Guo, Q., Kato, M., \& Ricklefs, R. (2003). Life history, diversity and distribution: a study of Japanese pteridophytes. a Journal of Space and Time in Ecology, 26(2), 129138. https://doi.org/10.1034/j.1600-0587.2003.03379.x.

Handayani, H., \& Widiantie, R. (2020). Pre-services biology teachers: correlation of metacognition awareness with the ability to design experiments through vee diagram. 
Biosfer: Jurnal Pendidikan Biologi, 143-154. https://doi.org/10.21009/biosferjpb.v13n1.143-154

Hanif, I., \& Rohman, F. (2016). Pengembangan perangkat pembelajaran biologi materi plantae berbasis inkuiri terbimbing terintegrasi nilai islam untuk meningkatkan pemahaman konsep siswa SMA. Jurnal Pendidikan, 1(11), 2163-2167. Retrieved from http://journal.um.ac.id/index.php/jptpp/article /view/8042/3665

Halimah, A. (2014). Metode cooverative integrated reading and learning composition (circ) dalam pembelajaran membaca dan menulis di sd/mi. AULADUNA, 1(1). 27-35. Retrieved from http://journal.uin-alauddin.ac.id/index.php/auladuna/article/view/539

Hamdani, M., Prayitno, B. A., \& Karyanto, P. (2020). Demonstration and experiment on archaebacteria and eubacteria: effectiveness for cognitive learning outcomes (CLO) based on critical thinking skill. Biosfer: Jurnal Pendidikan Biologi, 13(1), 75 - 85. https://doi.org/10.21009/biosferjpb.v13n1.75-85

Harahap, L. J., Ristanto, R. H., \& Komala, R. (2020). Getting critical thinking about ecosystem: How impact and responses of students about the CirGi learning model?. Biosfer: Jurnal Pendidikan Biologi, 13(1), 86-100. https://doi.org/10.21009/biosferjpb.v13n1.86-100

Hayati, N., \& Berlianti, N. A. (2020). Critical thinking skills of natural science undergraduate students on biology subject: Gender perspective. JPBI (Jurnal Pendidikan Biologi Indonesia), 6(1), 83-90.

Hayati, N. (2016). Peningkatan kesadaran metakognitif dan hasil belajar siswa SMA melalui penerapan diagram roundhouse dipadu model pembelajaran CIRC. EdHumanistics, 1(1), 44-55. Retrieved from http://ejournal.unhasy.ac.id/index.php/edhumanistics/article/view/15

Hindun, I., Nurwidodo, N., \& Wicaksono, A. G. C. (2020). Metacognitive awareness components of high-academic ability students in biology hybrid learning: Profile and correlation. JPBI (Jurnal Pendidikan Biologi Indonesia), 6(1), 31-38.

Howard, J. (2004). Development and validation of an objective measure of metacognition. Paper Presented At The Annual Meeting of The American Educational Research Association, 1(2), 18-22. Doi: https://doi.org/http://org.elon.edu/t2project/pdf_docs/sp_metacognitive.pdf

Hogan, M.J., Harney, O., Dwyer, C., \& Noone, C. (2015). Metacognitive skill development and applied systems science: a framework of metacognitive skills, self regulatory dungtions and real-world applications, 75-106. Retrieved from: https://link.springer.com/chapter/10.1007/978-3-319-11062-2_4\#citeas

Inayah, A.D., Ristanto, R.H., Sigit, D.V., Miarsyah, M. (2020). Analysis of science process skills in senior high school students. Universal Journal of Educational Research, 8(4A), 15-22. 
Iskandar, S.M. (2014). Pendekatan keterampilan metakognitif dalam pembelajaran sains di kelas. EDUCATIO, 2(2), 13-20. Retieved from http://ejournal.unhasy.ac.id/index.php/ed-humanistics/article/view/15

Ismirawati, N., Corebima, A.D., Zubaidah, S., Ristanto, R.H., Nuddin, A. (2020). Implementing ercore in learning: Will metacognitive skills correlate to cognitive learning result?. Universal Journal of Educational Research, 8(4A), 51-58.

Jannah, F. (2015). Penerapan model pembelajaran kooperative tipe stad dipadu inkuiri untuk meningkatkan aktivitas dan hasil belajar ipa siswa kelas v sdn 2 telang kabupaten hulu sungai tengah. Jurnal Paradigma, 10(1), 63-66. Retrieved from https://ppjp.ulm.ac.id/journal/index.php/paradigma/article /download/2841/2473

Kritpracha, C., Sae-Sia, W., Nukaew, O., Jittanoon, P., Chunuan, S., \& Kaosaiyaporn, O. (2018). The Development of Cooperative Learning Using Jigsaw Activities for Learning Achievement and Self-directed Learning Behaviors of Nursing Students. International Journal of Information and Education Technology, 8(12), 913-917.

Kusumaningtias, A., Zubaidah, S., \& Indriwati, S. E. (2013). Pengaruh problem based learning dipadu strategi numbered heads together terhadap kemampuan metakognitif, berpikir kritis, dan kognitif Biologi siswa kelas XI SMA Negeri 5 Malang. Jurnal Penelitian Kependidikan, 23(1), 33-47.

Leasa, M., Sanabuky, Y. L., Batlolona, J. R., \& Enriquez, J. J. (2019). Jigsaw in teaching circulatory system: a learning activity on elementary science classroom. $\begin{array}{llll}\text { Biosfer: Jurnal Pendidikan } & \text { Biologi, } & 122(2), & 134 .\end{array}$ https://doi.org/10.21009/biosferjpb.v12n2.122-134

Lestari, P., Ristanto, R. H., \& Miarsyah, M. (2019a). Metacognitive and conceptual understanding of pteridophytes: Development and validity testing of an integrated assessment tool. Indonesian Journal of Biology Education, 2(1), 15-24.

Lestari, P., Ristanto, R. H., \& Miarsyah, M. (2019b). Analysis of conceptual understanding of botany and metacognitive skill in pre-service biology teacher in Indonesia. Journal for the Education of Gifted Young Scientists, 7(2), 199-214.

Livingston, J. A. (2003). Metacognition: an overview. Education Resources Information Center, 1(14), 1-7. Retrieved from https://eric.ed.gov/?id=ED474273

Lukitasari, M., Sudilo. H., Ibrohim., \& Corebima. D. (2014). Lesson study in improving the role of e-portfolio on the metacognitive skill and concept comprehension: a study on cell Biology subject in IKIP PGRI Madiun, Indonesia. American Journal of Education Research, 2(10), 919-912.

Mahanal, S., Zubaidah, S., Sumiati, I. D., Sari, T. M., \& Ismirawati, N. (2019). RICOSRE: A Learning Model to Develop Critical Thinking Skills for Students with Different Academic Abilities. International Journal of Instruction, 12(2), 417-434.

Mariati, P. S. (2012). Pengembangan model pembelajaran fisika berbasis problem solving untuk meningkatkan kemampuan metakognisi dan pemahaman konsep 
mahasiswa. Jurnal Pendidikan Fisika Indonesia, 8(1), 152-160. Retrieved from https://doi.org/10.15294/jpfi.v8i2.2155

Meishanti, O. P. Y., Minah, F. N., \& Ami, M. S. (2018). Pengembangan Herbarium Pteridophyta Yang Diperoleh Di Area Wisata Kedung Cinet Jombang Sebagai Media Pembelajaran Botani Tumbuhan Rendah. JoEMS (Journal of Education and Management Studies), 1(2), 43-50.

Miharja, F. J., Hindun, I., \& Fauzi, A. (2019). Critical thinking, metacognitive skills, and cognitive learning outcomes: a correlation study in genetic studies. Biosfer: Jurnal Pendidikan Biologi, 12(2), 135-143. https://doi.org/10.21009/biosferjpb.v12n2.135-143

Muna, K., Haryani, S., \& Susilaningsih, E. (2016). Pengaruh guided inqury learning terhadap keterampilan metakognisi siswa dalam materi kelarutan dan hasil kali kelarutan. Journal of Innovative Science Education, 5(1), 19-27. Retrieved from http://joural.unnes.ac.id/sju/index.php/jise

Palennari, M. (2016). Exploring the correlation between metacognition and cognitive retention of students using some biology teaching strategies. Journal of Baltic Science Education, 15(5), 617-629. Retrieved from http://oaji.net/articles/2016/9871482502307.pdf

Pratama, A. T. (2018). Improving metacognitive skills using problem based learning (pbl) at natural science of primary school in deli serdang, indonesia. Biosfer: Jurnal Pendidikan Biologi, 11(2), 101-107. https://doi.org/10.21009/biosferjpb.v11n2.101-107

Pratiwi, I., Ismanisa, I., \& Nugraha, A. W. (2019). Development of guided inquiry based modules to improve learning outcomes and metacognition skills of student. Jurnal Pendidikan Kimia, 11(2), 49-56.

Prayitno, A.D. (2015). Keefektivan integrasi sintaks inkuiri terbimbing dan STAD (INSTAD) untuk memperkecil kesenjangan keterampilan metakognisi siswa akademik atas dan bawah. Jurnal Penelitian Sosial Keagamaan, INFERENSI, 9(2), 305-328. doi: http://dx.doi.org/10.18326 /infs13.v9i2.305-328

Rokhmat, J., \& Putrie, S. D. (2019). A Strategy of Scaffolding Development to Increase Students' Problem-Solving Abilities: The Case of Physics Learning with CausaliticThinking Approach. Journal of Turkish Science Education, 16(4), 569-579.

Ristanto, R., Rahayu, S., \& Mutmainah, S. (2020). Conceptual understanding of excretory system: Implementing cooperative integrated reading and composition based on scientific approach. Participatory Educational Research, 8(1), 28-47. https://doi.org/10.17275/per.21.2.8.1

Ristanto, R., \& Darmawan, E. (2020). Biology reading literacy: measurement and empowerment through circ learning model. Journal for the Education of Gifted Young Scientists, 8(4), 1305-1318. https://doi.org/10.17478/jegys.679378

Ristanto, R. H., Djamahar, R., Heryanti, E., \& Ichsan, I. Z. (2020). Enhancing students' biology-critical thinking skill through CIRC-Based scientific approach (Cirsa). 
Universal Journal of Educational Research, 8(4A), 1-8. https://doi.org/10.13189/ujer.2020.081801

Ristanto, R.H. (2017). Pengembangan perangkat pembelajaran integrasi cooperative integrated reading and composition (CIRC) dan inkuiri terbimbing serta pengaruhnya terhadap literasi sains dan penguasaan konsep Biologi mahasiswa PGSD universitas pakuan. (Disertasi, Universitas Negeri Malang, 2017).

Ristanto, R.H., Zubaidah, S., Amin, M., \& Rohman, F. (2018). From a reader to a scientist: developing cirgi learning to empower scientific literacy and mastery of biology concept. Biosfer: Jurnal Pendidikan Biologi, 11(2), 89-99. https://doi.org/10.21009/biosferjpb.v11n2.90-100

Ramdiah, S., \& Corebima, A.D. (2014). Learning strategy equalizing students' achievement, metacognitive, and critical thinking skills. American Journal of Educational Research, 2(8), 577-584. https://doi.org/10.12691 /education-2-8-3

Saputra, M. D., Joyoatmojo, S., Wardani, D. K., \& Sangka, K. B. (2019). Developing Critical-Thinking Skills through the Collaboration of Jigsaw Model with Problem-Based Learning Model. International Journal of Instruction, 12(1), 1077-1094.

Sarah, W., Widodo, F., Corebima, A. D., \& Mahanal, S. (2016). The contribution of metacognitive skills and motivation on the retention of senior high school. International Journal of Arts and Humanities, 1(2), 162-171.

Sari, A. P., Karyanto, P., \& Ashadi, A. (2020). Metacognitive awareness of commuter and resident students of Islamic high school in biology learning. JPBI (Jurnal Pendidikan Biologi Indonesia), 6(1), 25-30.

Schraw, G., Crippen, K. J., \& Hartley, K. (2006). Promoting self-regulation in science education: Metacognition as part of a broader perspective on learning. Research in Science Education, 36(1-2), 111-139. https://doi.org/10.1007/s11165-005-3917-8

Smith, A., Prayer, K. M., Schuettpelz, E., Korall, E., Schneider, H., \& Wolf, P.G. (2006). a classification of extant ferns. International of Association for Plant Taxonomy, $55,705-731$.

Sukiastini, I. G. A. N. K., Sadia, I. W., \& Suastra, I. W. (2013). Pengaruh model pembelajaran integrated reading and composition terhadap kemampuan pemecahan masalah dan berpikir kreatif. e-Journal Program Pascasarjana Universitas Pendidikan Ganesha, 3(1), 1-10.

Suraida. (2012). Identifikasi tumbuhan penghijauan sebagai media belajar Biologi. EduBio 3(1), 55-64.

Tjirosoedirdjo, S.S., \& Chikmawati, T. (2014). Sejarah Klasifikasi Dan Perkembangan $\begin{array}{llll}\text { Taksonomi } & \text { Tumbuhan } & \text { (e-book). } & \text { Retrieved }\end{array}$ http://repository.ut.ac.id/4359/1/BIOL4311-M1.pdf 
Tjitrosoepomo, G. (2010). Taksonomi tumbuhan (spermatophyta). Gadjah Mada University press, Yogyakarta.

Walker, J.P., Grooms, J., \& Sampson, V. (2012). Argument-driven inquiry undergraduate chemistry labs: the impact on students' conceptual understanding, argument skills, and attitudes toward. EBSCO, 41(1), 74-81. Retrieved from https://web.a.ebscohost.com/abstract?direct

Widyasari, M., Soekamto, H., \& Wirahayu, Y.A. (2013). Pengaruh penerapan model pembelajaran cooverative integrated reading and composition (circ) terhadap kemampuan berpikir kritis siswa pada mata pelajaran geografi sma, 1-11. Retrieved from: http://karyailmiah.um.ac.id/index.php/Geografi /article/view/26058

Yasir, M., Fikriyah, A., Qomaria, N., \& Al Haq, A. T. (2020). Metacognitive skill on students of science education study program: Evaluation from answering biological questions. JPBI (Jurnal Pendidikan Biologi Indonesia), 6(1), 157-164.

Yusnaeni, Y., Lika, A. G., \& Hiul, S. (2019). Human respiratory system: designing student worksheet based on inquiry to promote 21 st-century skills. Biosfer: Jurnal Pendidikan Biologi, $\quad$ 12(1), 34-44. https://doi.org/10.21009/10.21009/biosferjpb.v12n1.34-44

Yusuf, Q., Jusoh, Z., \& Yusuf, Y. Q. (2019). Cooperative Learning Strategies to Enhance Writing Skills among Second Language Learners. International Journal of Instruction, 12(1), 1399-1412. 